\title{
SPATIAL-TEMPORAL CONTINUUM AS A COGNITIVE AND LINGUACULTURAL DETERMINANT OF THE LITERARY GENRE IN THE NOVEL “THE BURIED GIANT” BY KAZUO ISHIGURO
}

\author{
Dametken Kurmanbaeva ${ }^{1}$, Batima Zhumagulova ${ }^{2}$ \\ ${ }^{1}$ Dametken Kurmanbaeva, PhD student, Kazakh Ablai khan University of International Relations \\ and World Languages, The Republic of Kazakhstan, Almaty, Kazakhstan, KAZAKHSTAN, \\ dametken1971@mail.ru \\ ${ }^{2}$ Batima Zhumagulova, candidate of philological sciences, associate professor, Kazakh Ablai khan \\ University of International Relations and World Languages, The Republic of Kazakhstan, Almaty, \\ Kazakhstan, KAZAKHSTAN, youmbs@mail.ru
}

\begin{abstract}
This article considers the problem of spatial-temporal continuum within the framework of cognitive linguistics. The spatial-temporal continuum is viewed as an inseparable element of the picture of the world. The cognitive-matrix model allows presenting a cognitive perception of a formal-substantial category of the literary 'chronotop' (M.M. Bakhtin) in the form of the concept "spatial-temporal continuum" as an organizational centre of the whole cognitive structure of the novel, determining its genre-type variety. According to the given approach, the cognitive-matrix model of spatial-temporal continuum develops the components which determine the main plot in K. Ishiguro's novel 'The Buried Giant". The integrative complicated concept 'spatial-temporal continuum' as a cognitive matrix represented in the system of cognitive contexts (structures of knowledge) includes concepts (memory -mist, path, journey) which belong to different conceptual fields and correlate with the past, present and future. The border between them is very fragile, transitions from one continuum to another can be made instantly. The peculiarity of K.Ishiguro's novel is in the parallel existence of several temporal-spatial models: natural, socio-cultural, philosophicalhistorical, mythological and others.
\end{abstract}

Keywords: space, time, spatial-temporal continuum, cognitive linguistics, concept, chronotop, cognitivematrix model, genre, picture of the world, language picture of the world.

\section{INTRODUCTION}

The article is aimed at identifying the peculiarities of space and time continuum from the viewpoint of cognitive linguistics in the novel "The Buried Giant" by Kazuo Ishiguro with the help of cognitive-matrix modeling.

The study of the spatial-temporal continuum (STC) in the novel "The Buried Giant" by Kazuo Ishiguro is developed on the notion of cognitive matrix by N.N. Boldyrev [Boldyrev, 2008, p. 5]. Reflection of space and time in the linguistic consciousness of the native speaker of language and culture is explored in the framework of cognitive linguistics as the main concepts of the linguistic picture of the world, and also in 
literary criticism as a category of chronotop that performs the plot-forming function in an artistic work.

Cognitive-matrix modeling is considered as a research technique in the system of cognitive-matrix analysis, which was proposed by N.N. Boldyrev to study units of a special format that cannot be correlated with standard knowledge [Boldyrev, 2008, p. 7]. The cognitive matrix combines knowledge of various aspects of the phenomenon into a system of different cognitive contexts, which in turn are represented integratively by its components in the frame of the whole complex concept. These contexts have the ability to differ at the level of complexity, and their content can be modified from the ordinary to the expert one [Boldyrev, 2009, p. 49].

\section{THE SPATIAL-TEMPORAL CONTINUUM}

The notion of the spatial-temporal continuum can be considered as the idea of the chronotop developed by one of the most famous Russian linguists M.M. Bakhtin. The introduction of the chronotop allowed the scientist to reconstruct the logic of the novels. M. M. Bakhtin proved that it is the chronotop of the novel which defines the exact genre in the literature and highlighted that the chronotop is the point of intersection of such elements of creativity as the plot, composition, themes, author's tasks, the individual style of the writer, the artistic method, and poetics. [Bakhtin, 1975, p.234]. The chronotop reproduces the space-time picture of the world and organizes the composition of the work. With the help of using the term Spatialtemporal continuum instead of chronotop we underline the cognitive approach to the study of this phenomenon in the novel "The Buried Giant' by Kazuo Ishiguro and the dialectical unity of time-spacematter.

The special theory of relativity combined three-dimensional space and one-dimensional time into a single four-dimensional spatial-temporal continuum which is considered as an obligatory component of any picture of the world. However, when analyzing the concept of STC, it is necessary to take into account its integrative nature, which is able to incorporate various conceptual areas into a single format of knowledge. This concept cannot be described by a simple set of mandatory and optional characteristics, in contrast to simple concepts. The STC functions as a single cognitive, linguacultural and genre-typical construct since the cognitive signs of the STC and its components determine the genre specificity of a work of art, often a synthesis of different genre characteristics within the framework of a complete artistic narrative of postmodernism.

First, it is necessary to note the extraordinary three axis nature of the spatial-temporal continuum in the novel, which is sharply conspicuous presented through the concepts (memory, path, journey). The problem here, however, is not only that the novel's action is concentrated on representing the spatial-temporal continuum (through memory and the mist- the time flows in one direction but then goes back) and the path under the open sky but in the several-day-journey as well. The imaged space is linked with the passage of time drawing into the "journey" line. Time flows in one direction towards to the aim- Axl and Beatrice want to find their son. The time is divided into a series of adventurous segments, within which it is organized abstractly-technically; its connection with space is also technical.

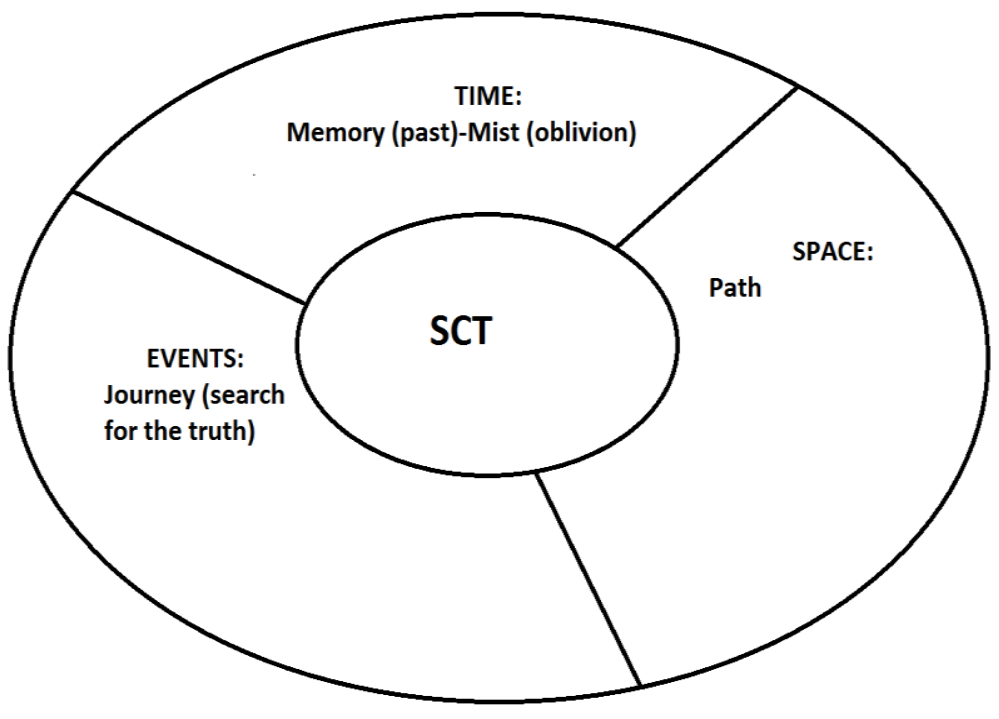

FIG. 1 Integrative Cognitive-Matrix Model (N.N. Boldyrev) of the Spatial-Temporal Continuum 
The STC of the novel is a set of the main concepts which organize the whole unity of the novel: memory, path, journey.

In this article there has been made an attempt to define conceptual fields of Memory in contrast to Mist as Oblivion manifesting the past and their characteristics from the author's point of view.

It is supposed, that the diverse, multi-planned concept "Memory" includes the following conceptual fields: private-personal, socio-cultural, philosophical-historical, mythological ones within which some meaning generating processes occur. Memory can be considered as the structure of Time which functions as the basis of philosophical understanding of being. The main characters of the novel set off on the journey in order to dispel the mist and restore their memory. It is the mist that covers the memory of the people and causes fragmentariness and vagueness of the world perception which results in instability, unsteadiness of their present existence. Without the awareness of the past there is no self-identity in the present.

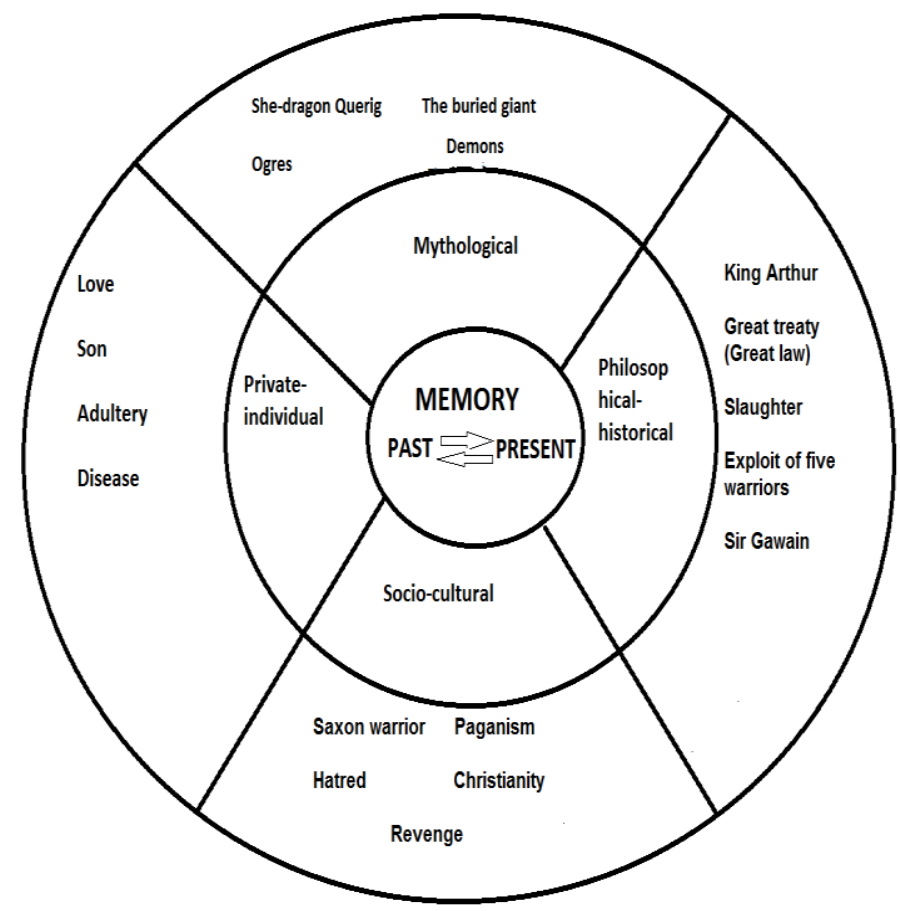

FIG. 2 Conceptual Field of Memory as a Part of the Spatial-Temporal Continuum

\subsection{Private-Personal Cognitive Context of Memory}

The Private-personal conceptual field is represented in the description of the family life of the main characters called Axl and Beatrice who are devoted to each other and have vague images of their previous living. The whole plot of the novel is focused on their search for private-personal memory since their wish of family reunion and the meeting with the boatman disclosed the lacuna in their picture of the past life. The restoration of the memory would lead them to holistic life picture and full self-identity.

The space where Axl and Beatrice lived was shown as dark and frightening (miles of desolate, uncultivated land, rough-hewn paths over craggy hills or bleak moorland, broken or overgrown roads, often fading into wilderness, such gloomy spots). "Closed space (shelters, castle), compared to the Saxon village that would have been something more familiar to you as a "village" than AxI and Beatrice's warren. ...". The Saxon village was shown as opposite to the dark village of Axl and Beatrice: "....variations in size and splendor, ... a tall fence of tethered timber poles, their points sharpened like giant pencils, completely encircled the village. .... a deep trench followed it all the way around the outside." [Ishiguro, 2015, p.18]. They have a happy life: "It's like a tale with a happy end, when even a child knows not to fear the twists and turns before". They are eager to know the truth: "AxI and I would remember our life together, whatever its shape, for it's been a thing dear to us." [ Ishiguro, 2015, p.68].

Sometimes time becomes uncertain like in a fairy tale when Axl dreams about the past: "Perhaps there had been a time when they had lived closer to the fire; a time when they had lived with their children." [ Ishiguro, 2015, p.5].

The Private-personal conceptual field is represented with the following concepts: love, son, adultery, 
disease.

Love is a basic human notion. The love of $A x I$ and Beatrice is characterized with the following lexical units: princess, my master, my one true love. Their love is expressed in the main characters' actions as signs of:

- A mutual understanding between each other: "an understanding had grown between them, in the silent way understandings do between a husband and wife of many years" [Ishiguro, 2015, p.9] and sometimes it is possible not to discuss the subjects they do not want to: "to avoid the subject as much as possible." [Ishiguro, 2015, p.9].

- A great support to each other in difficult situations. For example, the community wanted to take the candle from Beatrice and she did not to give it back and when Axl came and she had "one of overwhelming relief. It was not that Beatrice had believed all would be well once he had arrived; but his presence had made all the difference to her. She had gazed at him not just with relief, but also something like pleading, and held out to him the object she had been jealously guarding." [Ishiguro, 2015, p.9.]

- A great care of each other: "Axl took a great care about his wife .. She moved closer to him, letting her head fall on his shoulder. ...Putting an arm around her, Axl trapped the cloak and held it tightly to her." [Ishiguro, 2015, p. 13].

- A great devotion to each other noticed by other people: "I saw your unusual devotion to each other" (the boatman said)[Ishiguro, 2015, p.131].

- Respect, politeness, trust to each other's decision: “I wouldn't tell you any such thing, princess, for I see for myself what you're saying is true." [Ishiguro, 2015, p.7]. I told you I was just teasing and I won't do so again." [Ishiguro, 2015, p.7].

They had a true love though the boatman said that "the eternal love is an exception: A couple may claim to be bonded by love, but we boatmen may see instead resentment, anger, even hatred. Or a great barrenness. Sometimes a fear of loneliness and nothing more. Abiding love that has endured the years that we see only rarely. When we do, we're only too glad to ferry the couple together" even though they go to the island separately: "Farewell then, Axl." "Farewell, my one true love." [Ishiguro, 2015, p.135].

The image of their Son is vague but described with the following positive lexical units and expressions: a fine and good man, I know that for sure.... A fine, strong, upright man; evaluation and neutral nominations which characterize appearance and personality: "But I can't remember our son, neither his face nor his voice, though sometimes I think I can see him when he was a small boy, and I'm leading him by the hand beside the riverbank, or when he was weeping one time and I was reaching out to comfort him. But what he looks like today, where he's living, if he has a son of his own, I don't remember at all." [Ishiguro, 2015, p.11]. "So I can feel things about him, even if I don't remember clearly. "[Ishiguro, 2015, p.11] But at the same time they think their son will take care of them: And I know he longs for us to leave this place and be living with him under his protection. He'll protect us and see no one treats us ill." [Ishiguro, 2015, p.10]. " $A$ strong, handsome face, that much I remember. But the colour of his eyes, the turn of his cheek, I've no memory of them." [Ishiguro, 2015, p.13] but the elderly couple think "it's cruel when we can't remember a precious thing like that. He's our flesh and blood... ." [Ishiguro, 2015, p.13].

They are confident that their son needs their love and presence: "Our son awaits us in his village. How much longer must we keep him waiting." [Ishiguro, 2015, p.8].

Their son is described in the way all parents see their children: handsome, kind, reliable and will take care of them.

Adultery is in the past. The mist influences the people's relations, including Axl and Beatrice who love each other very much and their love seems to be deep but again they are not confident in it since some memories of their past adultery follow them.

Disease appears to be a check of their feeling to each other. Each of them tries not to trouble another: "AxI had been anxious about his wife's stamina." [Ishiguro, 2015, p.12] while Beatrice call it "a small discomfort" 'Without turning to him, she pressed a hand to her side, just below the ribcage." [Ishiguro, 2015, p.21].

There were given some symptoms of her disease (e.g. below the ribcage, blood in her urine), not the name of it. The word 'sickness' is used instead of disease to show the Beatrice's attitude to it.

Thus, we found out that the family life described showed the signs of strong tender love of the couple to each other. In spite of some hardships they experienced (adultery, illness) they stayed together till the end.

The conceptual field private-personal determines the genre of a fairy tale. 


\subsection{Socio-Cultural Cognitive Context of Memory}

The Social-Cultural conceptual field is represented through the interaction of concepts: castle, Saxon warrior, hatred, revenge, paganism and Christianity which reflect the Briton-Saxon interrelations at that historical time (lifestyle, traditions, religion, governing) and a difficult way (hatred, revenge) to the national united community.

The Briton castle (monastery) is saturated with the time and plays a rather important role in the development of any historical novel and is of polifunctional character: in the novel in different periods of history it serves as a fortress, castle, monastery and prison. Castle comes from the past centuries and turns to the past, so traces of time in it are somewhat of archaic-historical character. Organic cohesion in the castle (with its surroundings) of spatial and temporal moments takes place, the historical intensity of this chronotop determined its pictorial productivity at different stages of development of the historical novel.

Saxon warrior, Master Wistan, stresses that he is not a Briton but Saxon who grew up among Britons: "My blood is Saxon through and through, but I was brought up in a country not far from here and was often among Britons. So I learnt to speak your tongue alongside my own. These days I'm less accustomed to it, living as I do far away in the fenlands, where one hears many strange tongues but not yours." [Ishiguro, 2015, p.31].

-It is Wistan's duty to keep peace: "I fear this Lord Brennus is one who would undo the great peace won by Arthur." [Ishiguro, 2015, p.54].

Wistan has a special deed in that place "It's my king's fear Lord Brennus means to capture Querig to fight in the ranks of his army. This she-dragon would make a fierce soldier indeed, and Brennus would then rightly harbour ambition. It's for this I'm sent to destroy the dragon before her savagery turns on all who oppose Lord Brennus." [Ishiguro, 2015, p.54].

Hatred is a feeling that every Saxon must have to Britons and Wistan calls his previous love to Britons "an error, a shame". He is grateful for Lord Brennus who does not allow to forget his origin and hatred of Saxons to Britons. His previous affection to Britons turned into the hatred: "But today l've reason to be grateful to Lord Brennus, for he saved me from a pitiable fate. l've told you already, Master Edwin, I'd begun to love my companions in that fort as my own brothers, even though they were Britons and I a Saxon." ..... I feel shame even now remembering the affection I had for them. But it was Brennus showed me my error.... And he was not slow to notice I was a Saxon boy, and before long, turned each of my companions against me on that account. Even those once closest to me joined against me, spitting in my food, or hiding my clothes as we hurried to our training on a harsh winter's morning, fearful of our teachers' wrath. It was a great lesson Brennus taught me then... ." [Ishiguro, 2015, p. 94]. That hatred to Britons makes Wistan take a revenge.

The syntactic parallelism 'even' and the antithesis 'love-hatred' is used to demonstrate the struggle between the tribes. The people have to choose between 'extreme love' and 'extreme hatred' because of the policy of King Arthur on the one hand and Lord Brennus - on the other hand. People have to balance between the policies which orientate them at the two extremes.

Paganism and Christianity. The writer shows medieval times when people believed in God but the influence of paganism was still strong. Throughout the novel the medieval people have a strong belief in God (even King Arthur could not be higher than God) while still living deeply in the world of mystic creatures.

The analysis allows lining up a genre of historical drama where growing up among Britons Master Wistan throughout his life wanted to take a revenge of Britons who murdered his family and his Saxon people.

\subsection{Philosophical -Historical Cognitive Context of Memory}

The Philosophical-historical conceptual field is represented with the help of the following interrelated concepts: King Arthur, great treaty (great law), slaughter, exploit of five warriors, Sir Gawain. The given concepts complex presents a wide range of philosophical, ethical, historical-political problems of the novel: means of achieving goals, the manipulation of collective consciousness, covering the collective memory by the mist. The main conflict of the novel plot consists of contradictions of the Axl's "great treaty" as the first diplomatic attempt to keep peace between Saxons and Britons opposed to King Arthur's "slaughter" and "exploit of five warriors".

Axl's "great treaty" is aimed at making a peaceful agreement between Saxons and Britons which brought "men closer to God" but "That great law you brokered torn down in blood! Yet it held well for a time. Torn down in blood!" [Ishiguro, 2015, p.114]. The treaty fails because King Arthur does not trust Saxons and 
orders to slaughter them to eradicate the revenge feelings of enemies.

The metaphor 'Torn down in blood' is used to highlight the failure of the important treaty, its physical eradication. Simultaneously subjective-evaluative epithet 'great treaty-great law' are used to signify the importance of it.

King Arthur is a legendary hero of the Britons of the $5^{\text {th }}-6^{\text {th }}$ centuries who defeated Saxons. The lexical units are used to describe King Arthur: generous, fairness, wisdom, justice.

The author defines the contradictory personality of King Arthur:

On the one hand he seems to be:

- A brave warrior: "Arthur was once such a dreaded enemy."[shiguro, 2016, p.48].

- A generous man: "For Arthur was one so generous to those he defeated they soon grew to love him as their own." [Ishiguro, 2015, p.48]

- As fair: "My reply is that my uncle was a ruler never thought himself greater than God, and always prayed for guidance. So it was that the conquered, no less than those who fought at his side, saw his fairness and wished him as their king". [Ishiguro, 2015, p.48]

- A loved king: "Our beloved Arthur brought lasting peace here between Briton and Saxon, and though we still hear of wars in distant places, here we've long been friends and kin." [Ishiguro, 2015, p.48].

On the other hand in this novel King Arthur is described not only as a noble man but as a cruel slaughterer as well: “... isn't it a strange thing when a man calls another brother who only yesterday slaughtered his children? And yet this is the very thing Arthur appears to have accomplished." "You touch the heart of it just there, Master Wistan. Slaughter children, you say. And yet Arthur charged us at all times to spare the innocents caught in the clatter of war. More, sir, he commanded us to rescue and give sanctuary when we could to all women, children and elderly, be they Briton or Saxon. On such actions were bonds of trust built, even as battles raged."

[Ishiguro, 2015, p.49].

Slaughter is the way King Arthur defeated Saxons. The author uses repetition to stress the horror of the deed done by King Arthur: "Though today we slaughter a sea of Saxons, be they warriors or babes, there are yet many more across the land. They come from the east, they land by ship on our coasts, they build new villages by the day. This circle of hate is hardly broken, sir, but forged instead in iron by what's done today. I'll go now to your uncle and report what l've seen. I would see from his face if he believes God will smile on such deeds." [lshiguro, 2015, p. 91].

"A slaughterer of babes. Is that what we were that day? ....Let an old man go in peace. A slaughterer of babes. Yet I was not there, and even had I been, what good for me to argue with a great king, and he my uncle too." [Ishiguro, 2015, p. 91].

Axl was a participant of the slaughter and Wistan recognizes him: "Master Wistan," Axl said, "I've seen you look strangely at me from time to time since our first meeting, and waited for some account of it. What is it you believe me to be?" [Ishiguro, 2015, p.49]. "Your husband's face has all day promised me an important remembrance, and if truth be told, that was a reason for my proposing to travel with you, though I sincerely wish to see you both safely through these wild roads." "But why would you know my husband from the west when he's always lived in country nearby...? He went on looking at Axl silently, his eyes almost dreamlike. Then his face darkened, and rising to his feet again, the warrior turned away." [Ishiguro, 2015, p.47].

The simile 'dreamlike' and metaphor 'his face darkened' are used to intensify Mr. Wistan's great anxiety of the past events which do not let him stay calm and made him choose the way of his present duty.

Exploit of five warriors. King Arthur sent five warriors to help Merlin make the dragon spread the mist over the country to make people forget about the war to keep the peace between Britons and Saxons. Despite it, the revenge is not forgotten by both Saxons and Britons: Saxons want to take a revenge of the slaughter by king Arthur while Britons are afraid that making Querig a servant of Lord Brennus it will be used as a kind of weapon by Britons: "If Querig is made a servant of Lord Brennus, it will surely tempt new wars." [Ishiguro, 2015, p.47] In fact, the past is not forgotten and both sides desire the war: "My king sent me to destroy this she-dragon not simply to build a monument to kin slain long ago. You begin to see, sir, this dragon died to make ready the way for the coming conquest." "Yet who knows what old hatreds will loosen across the land now? We must hope God yet finds a way to preserve the bonds between our peoples, yet custom and suspicion have always divided us. Who knows what will come when quick-tongued men make ancient grievances rhyme with fresh desire for land and conquest?" [Ishiguro, 2015, p.126]. 
The usage of the subjective epithet 'quick-tongued' and metaphor 'rhyme' help to describe the policy and political games of Lord Brennus who wants to make use of the she-dragon in the new war.

Sir Gawain first introduces himself as a noble man: "I'm Gawain, right enough, nephew of the great Arthur who once ruled these lands with such wisdom and justice. I was settled many years in the west, but these days Horace and I travel where we may." [Ishiguro, 2015, p.49].

His duty was ... "to slay Querig, Master Wistan! Horace and I have laid careful plans to lure her out and we seek no assistance!" [Ishiguro, 2015, p.52] but later it turned out to be a lie: "Let's keep no more disguises between us. You're the she-dragon's protector, are you not?" "I am, sir." Gawain gazed at each of them in turn, Edwin included, with an air of defiance. "Her protector, and lately her only friend. The monks kept her fed for years, leaving tethered animals at this spot, as you do. But now they quarrel among themselves, and Querig senses their treachery. Yet she knows I stay loyal." [Ishiguro, 2015, p. 118].

The novel works as an adventurous time as in any other chivalric novel. The knighthood represented by Sir Gawain is different. However, he follows the same principles of knighthood when he promised Sir Arthur to protect Querig: by this he demonstrates his loyalty to King Arthur.

The presented concepts allow lining up the mixture of the chivalric novel and parable genres. The characteristics of the chivalric novel are vivid while the parable genre is given implicitly (keeping peace by eradicating people's memory about the past which is a sign of manipulation of collective consciousness).

\subsection{Mythological Cognitive Context of Memory}

There is some play between time (generalized and concrete) and space where myths, fantasy and real definite history events work as one unity. From one - real earth spatial-temporal continuum the characters move to another- a mythological spatial-temporal continuum (the scenes with ogres, the dragon, etc.) which was ordinary for medieval people. The author shows the historical events in the close connection with the scenes where the main characters of the novel encounter with the mystic creatures. Mythological space and mythological time do not have any border: it is infinite and endless.

The Mythological conceptual field is manifested in the following myths: about she-dragon Querig, ogres, demons, the buried giant, etc. The simultaneous usage of different kinds of the myths in one novel shows the author's intention to reflect the beliefs, lifestyle, traditions, superstitions, fears of the people in the medieval period of the British history.

She-Dragon Querig is from the myth about King who decided to build a fortress. The dragon represents an evil inclination, the embodiment of human fears, a destructive force: "By all accounts Querig's a dragon of great fierceness, and hidden in difficult terrain." [Ishiguro, 2015, p.28]. Querig spreads the mist.

Ogres are hideous giants usually represented in fairy tales and folklore as man-eating creatures. In this novel ogres represent evil that people have to fight with, however, ogres were not dangerous for people "... such monsters were not cause for astonishment. People then would have regarded them as everyday hazards, and in those days there was so much else to worry about." [Ishiguro, 2015, p.10]. Apart from the myth about ogres the author uses the myths about other mystic creatures like demons, a wolf-like beast etc.

The buried giant represents the war that can break out between Saxons and Britons. Master Wistan warns, "The giant, once well buried, now stirs. When soon he rises, as surely he will, the friendly bonds between us will prove as knots young girls make with the stems of small flowers. Men will burn their neighbours' houses by night. Hang children from trees at dawn. The rivers will stink with corpses bloated from their days of voyaging. And even as they move on, our armies will grow larger, swollen by anger and thirst for vengeance. For you Britons, it'll be as a ball of fire rolls towards you. "[Ishiguro, 2015, p.126].

The presented myths used by Kazuo Ishiguro line up the genre of prose magic depicting magic and unreal elements as natural in realistic surrounding.

\section{CONCLUSION}

The analysis allows concluding that in the basis of the STC of the novel there is a complex conceptual matrix which presents the system of the main concepts (Memory, Path, Journey) manifesting dialectics of TimeSpace-Events continuum. The functioning of the novel STC was demonstrated on the example of just one element "Memory" which has a philosophical importance through the opposition of two types of human consciousness (fragmentary and holistic) as well as the necessity of the past to transform the present with the focus on the future.

1. The concept "Memory" consists of the parallel existence of several temporal-spatial models: private- 
personal, socio-cultural, philosophical- historical, mythological.

2. Private-personal memory is the search of the couple to fill the lacuna in the picture of their previous life to be aware of their present relationships. The restoration of the memory would lead them to holistic life picture and full self-identity.

3. Social-Cultural memory is concentrated on the reflection of the Briton-Saxon interrelations at different levels (lifestyle, traditions, religion, governing) at that historical time and a difficult way (hatred, revenge) to the national united community.

4. Philosophical-historical memory discusses the ways of keeping peace among Saxons and Britons, how the rulers manipulate people's consciousness by deleting their memory about the past (slaughter, victims of war) and creating political myths. The problem of using appropriate instruments to achieve political aims is still actual.

5. Mythological memory is a must to reflect the ideology of those medieval times. Myths are inseparable parts of their beliefs, lifestyle, traditions, superstitions, fears. The myths "She-dragon Querig" and "The Buried Giant" are used as means of manipulations and as a note of warning simultaneously.

6. The STC represents the novel "The Buried Giant" by Kazuo Ishiguro as a multigenre narrative. The genre syncretism of a fairy tale, a historical drama, a chivalric novel, a parable and a prose magic as realization of the novel "The Buried Giant" spatial-temporal continuum is observed. The border between them is very fragile; transitions from one continuum to another can be made instantly.

\section{REFERENCE LIST}

Bakhtin M.M. Voprosyi literaturyi i estetiki. - M.: Hudozh. lit., 1975. - S.234-407.

Boldyirev N.N., Alpatov V.V.(2008) Kognitivno-matrichnyiy analiz angliyskih hristianskih toponimov // Voprosyi kognitivnoy lingvistiki. \#4. p. 5-15.

Boldyirev N.N. (2009) Kontseptualnaya osnova slova // Kognitivnyie issledovaniya yazyika. Vyip. IV // Kollektivnaya monografiya. - M. - p.25-78.

Ishiguro Kazuo The Buried Giant: Knopf, 2015- p.135, https://www.rulit.me/books/the-buried-giant-get381857.html 